\title{
Radon Activity Concentrations in Natural Hot Spring Water: Dose Assessment and Health Perspective
}

\author{
Eka Djatnika Nugraha ${ }^{1,2}$ (), Masahiro Hosoda ${ }^{2,3}{ }^{(\mathbb{D}}$, June Mellawati ${ }^{1}$, Untara Untara ${ }^{1}$, Ilsa Rosianna ${ }^{4}$, \\ Yuki Tamakuma ${ }^{2,3}$, Oumar Bobbo Modibo ${ }^{2}{ }^{\mathbb{D}}$, Chutima Kranrod ${ }^{3}{ }^{1}$, Kusdiana Kusdiana $^{1}$ \\ and Shinji Tokonami ${ }^{3, *}$ (i) \\ 1 Centre for Technology of Radiation Safety and Metrology, National Nuclear Energy Agency of \\ Indonesia (BATAN), Jakarta 12440, Indonesia; eka.dj.n@batan.go.id (E.D.N.); \\ june_mellawati@batan.go.id (J.M.); tara@batan.go.id (U.U.); kusdiana@batan.go.id (K.K.) \\ 2 Department of Radiation Science, Graduate School of Health Sciences, Hirosaki University, \\ Hirosaki 036-8504, Japan; m_hosoda@hirosaki-u.ac.jp (M.H.); tamakuma@hirosaki-u.ac.jp (Y.T.); \\ h19gg701@hirosaki-u.ac.jp (O.B.M.) \\ 3 Institute of Radiation Emergency Medicine, Hirosaki University, Hirosaki 036-8504, Japan; \\ kranrodc@hirosaki-u.ac.jp \\ 4 Centre for Nuclear Minerals Technology, National Nuclear Energy Agency of Indonesia (BATAN), \\ Jakarta 12440, Indonesia; ilsa.r@batan.go.id \\ * Correspondence: tokonami@hirosaki-u.ac.jp; Tel.: +81-172-39-5404
}

check for updates

Citation: Nugraha, E.D.; Hosoda, M.; Mellawati, J.; Untara, U.; Rosianna, I.; Tamakuma, Y.; Modibo, O.B.;

Kranrod, C.; Kusdiana, K.; Tokonami, S. Radon Activity Concentrations in Natural Hot Spring Water: Dose Assessment and Health Perspective. Int. J. Environ. Res. Public Health 2021, 18, 920. https://doi.org/10.3390/ ijerph18030920

Academic Editor: Paul B. Tchounwou Received: 25 December 2020

Accepted: 20 January 2021

Published: 21 January 2021

Publisher's Note: MDPI stays neutral with regard to jurisdictional claims in published maps and institutional affiliations.

Copyright: (c) 2021 by the authors. Licensee MDPI, Basel, Switzerland. This article is an open access article distributed under the terms and conditions of the Creative Commons Attribution (CC BY) license (https:/ / creativecommons.org/licenses/by/ $4.0 /)$.

Abstract: The world community has long used natural hot springs for tourist and medicinal purposes. In Indonesia, the province of West Java, which is naturally surrounded by volcanoes, is the main destination for hot spring tourism. This paper is the first report on radon measurements in tourism natural hot spring water in Indonesia as part of radiation protection for public health. The purpose of this paper is to study the contribution of radon doses from natural hot spring water and thereby facilitate radiation protection for public health. A total of 18 water samples were measured with an electrostatic collection type radon monitor (RAD7, Durridge Co., USA). The concentration of radon in natural hot spring water samples in the West Java region, Indonesia ranges from 0.26 to $31 \mathrm{~Bq} \mathrm{~L}^{-1}$. An estimate of the annual effective dose in the natural hot spring water area ranges from 0.51 to $0.71 \mathrm{mSv}$ with a mean of $0.60 \mathrm{mSv}$ for workers. Meanwhile, the annual effective dose for the public ranges from 0.10 to $0.14 \mathrm{mSv}$ with an average of $0.12 \mathrm{mSv}$. This value is within the range of the average committed effective dose from inhalation and terrestrial radiation for the general public, $1.7 \mathrm{mSv}$ annually.

Keywords: radon; hot spring; dose assessment; public health

\section{Introduction}

Odourless and originating from radium-226 $\left({ }^{226} \mathrm{Ra}\right)$ decay that naturally occurs in the earth's crust, radon is a radioactive noble gas. According to the United Nations Scientific Committee on the Effects of Atomic Radiation (UNSCEAR), half of the world's mean value of annual effective dose by natural radiation sources is attributed to ${ }^{222} \mathrm{Rn}$, thoron $\left({ }^{220} \mathrm{Rn}\right)$ and their progenies [1]. Radon $\left({ }^{222} \mathrm{Rn}\right)$ has been recognised as a carcinogenic gas and is well-known as the second leading health risk factor for lung cancer [1-3]. Radon from water contributes to the total inhalation risk associated with radon in indoor air. In addition to this, drinking water contains dissolved radon and the radiation emitted by radon and its radioactive decay products exposes sensitive cells in the stomach as well as other organs once it is absorbed into the bloodstream. Noting this danger, the United States Environmental Protection Agency (EPA) proposed a maximum contaminant level (MCL) for radon in the water around $11 \mathrm{~Bq} \mathrm{~L}^{-1}$ [4].

Radon dissolves in water that passes through soil and rock containing the natural radioactive substance $[5,6]$. As a result, water moving deeper through the earth's crust 
gathers increasing concentrations of radon and other natural radioactive materials. When, during the geothermal process, temperatures and pressures increase enough, some of this water is expelled through faults and cracks, reaching the earth's surface as hot springs. Hot spring water produced under these circumstances usually contains high concentrations of ${ }^{222} \mathrm{Rn}$. This is due to at least one of two natural processes: ${ }^{226} \mathrm{Ra}$ dissolving in the water after interacting with rock and soil in the earth or ${ }^{222} \mathrm{Rn}$ entering the water from rocks containing ${ }^{226} \mathrm{Ra}[6-8]$.

The world community has long used natural hot springs for tourist and medicinal purposes. In Indonesia, the province of West Java, which is naturally surrounded by volcanoes, is a prime hot spring tourist destination. Approximately 1.8 million tourists visit natural hot springs in the West Java province each year [9-11].

It is, therefore, necessary to study the contribution of ${ }^{222} \mathrm{Rn}$ doses from natural hot spring water as part of radiation protection for public health. This paper is the first report on ${ }^{222} \mathrm{Rn}$ measurements in tourism natural hot spring water in Indonesia. Previous studies related to radon measurements in Indonesia included measurements of air at dwellings [12-15], ${ }^{222} \mathrm{Rn}$ in water samples [15], ${ }^{222} \mathrm{Rn}$ in geothermal and geosciences [16]

\section{Materials and Methods}

\subsection{Study Area}

This research was conducted in several districts in West Java, including the Ciater Hot Springs area in Subang; the Ciwidey and Pangalengan Hot Springs areas in Bandung; and the Cipanas and Darajat Hot Springs areas in Garut. Each of these hot springs is a major tourist destination, as shown in Figure 1. Visited by approximately 300,000 tourists each year, the Ciwidey and Pangalengan areas are tourist destinations located on the Patuha volcano. The Ciater Hot Spring, located on the Tangkuban Perahu volcano, is the most popular area for hot spring tourism with approximately 1.3 million visitors annually. Finally, as many as 50,000 tourists visit the Cipanas and Darajat areas every year [9-11]. The Cipanas area is located on the Guntur volcano, and the Darajat area is on the Kamojang volcano, which also has a geothermal power plant.

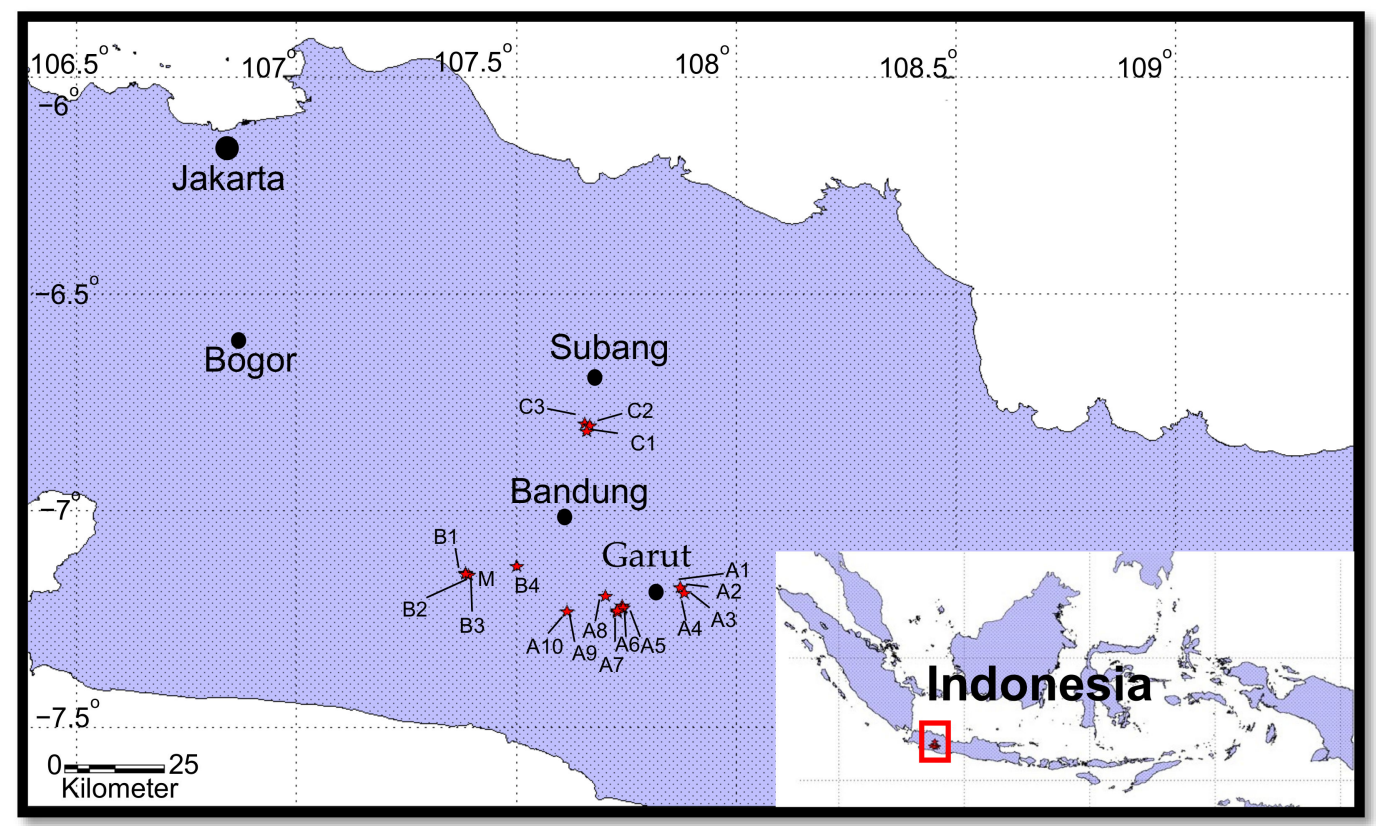

Figure 1. The study area, covering three cities: Bandung, Subang, and Garut. The black dots represent cities, and red asterisks indicate sampling locations. 


\subsection{Radon Measurement in Water Samples}

A total of 18 water samples of $250 \mathrm{~mL}$ each were collected using radon-tight reagent bottles as part of the water analysis accessory (RAD-H2O, Durridge Co., USA). This study was conducted in September 2019, which includes the dry season. The samples included 17 natural hot springs water samples and one mineral water sample. The samples were measured for temperature, $\mathrm{pH}$, and electroconductivity (E.C.) (Laquatwin, Horiba, Japan). In addition, the ambient dose equivalent rates (PDR-111, Hitachi, Japan) around the sampling area were measured. An electrostatic collection type ${ }^{222} \mathrm{Rn}$ monitor (RAD7, Durridge Co., USA) connected to a water analysis accessory was used to measure the samples and detect alpha activity. The RAD7 detector connected the monitor with a bubbling kit for degassing of ${ }^{222} \mathrm{Rn}$ in a water sample into the air in a closed circuit, as shown in Figure 2. Before the ${ }^{222} \mathrm{Rn}$ arrived at the detector, it also needed to be dried with a desiccant $\left(\mathrm{CaSO}_{4}\right.$, Drierite, W A Hammond, USA) to absorb the moisture.

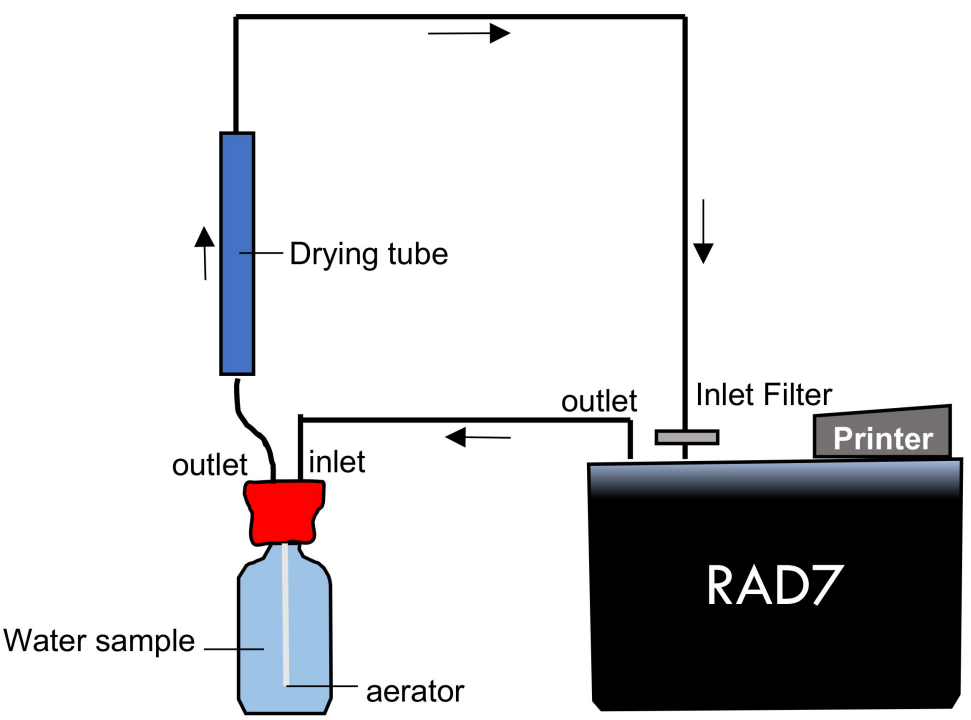

Figure 2. Schematic of experimental setup for measuring dissolved ${ }^{222} \mathrm{Rn}$ measurement

We used the WAT250 protocol in five-minute cycles and five recycles to generate data. In this measurement protocol for grab samples analysis, the pump ran for five minutes, flushing the measurement chamber, and then stopping. The RAD7 waited for five additional minutes at the end of the run before printing a summary. Since the analysis was made more than an hour after the sample was taken, a correction was applied to account for ${ }^{222} \mathrm{Rn}$ decay [17]. The amount of radon loss was calculated using the decay formula, or Equation (1):

$$
C_{t}^{\prime}=C_{0}^{\prime} A e^{-\lambda t^{\prime} / 60}
$$

where $C_{t}^{\prime}\left(\mathrm{Bq} \mathrm{m}^{-3}\right)$ is the ${ }^{222} \mathrm{Rn}$ activity concentration at time $t^{\prime}(\mathrm{min}) ; C_{0}^{\prime}$ is the ${ }^{222} \mathrm{Rn}$ activity concentration at time $t^{\prime}=0$; and $\lambda$ is the ${ }^{222} \mathrm{Rn}$ decay constant $\left(7.542 \times 10^{-3} \mathrm{~h}^{-1}\right)$.

\subsection{Radon Measurement in the Air}

We measured the ${ }^{222} \mathrm{Rn}$ activity concentration in the air $1 \mathrm{~m}$ above the hot spring pool with RAD7 for $8 \mathrm{~h}$. An 'auto' mode was used to obtain this measurement in 60 min cycles, and eight recycles were allowed. ${ }^{222} \mathrm{Rn}$ measurements began with the sniff mode before changing automatically to the normal mode after $3 \mathrm{~h} 45 \mathrm{~min}$. The results obtained were then averaged. We also measured the ${ }^{222} \mathrm{Rn}$ activity concentration in the dwelling around each natural hot spring area as the background for estimating the transfer coefficient from ${ }^{222} \mathrm{Rn}$ in the water to ${ }^{222} \mathrm{Rn}$ in the air. 


\subsection{Estimation of Annual Effective Dose}

We used Equation (2) to calculate the contribution of ${ }^{222} \mathrm{Rn}$ in the water to ${ }^{222} \mathrm{Rn}$ in the atmosphere. Meanwhile, the internal annual effective dose from ${ }^{222} \mathrm{Rn}$ through inhalation, the annual effective dose from external radiation, and the annual effective dose are shown in Equations (3)-(5), respectively.

$$
\begin{gathered}
D_{R n-w}=C_{R n-w} \times T F_{R n-w-a}, \\
E_{i n(R n)}=C_{R n} \times F \times D C F_{R n P} \times \mathrm{T}, \\
E_{\text {ext }}=H^{*} \times \mathrm{CF} \times D C F_{H-D} \times \mathrm{T}, \\
\mathrm{AED}=E_{\text {ext }}+E_{i n-R n} .
\end{gathered}
$$

In Equation (2), $D_{R n-w}$ is the ${ }^{222} \mathrm{Rn}$ activity concentration contributed from water to the atmosphere $\left(\mathrm{Bq} \mathrm{m}^{-3}\right) ; C_{R n-w}$ is the ${ }^{222} \mathrm{Rn}$ activity concentration in the water samples $\left(\mathrm{Bq} \mathrm{L}{ }^{-1}\right)$; and $T F_{R n-w-a}$ is the transfer coefficient from water to air, which equals $1 \times 10^{-4}[18,19]$. In Equation (3), $E_{i n(R n)}$ is the internal annual effective dose from ${ }^{222} \mathrm{Rn}$ through inhalation $(\mathrm{mSv}) ; \mathrm{C}_{R n}$ is the ${ }^{222} \mathrm{Rn}$ activity concentration in the $\operatorname{air}\left(\mathrm{Bq} \mathrm{m}{ }^{-3}\right) ; \mathrm{F}$ is the equilibrium factor of ${ }^{222} \mathrm{Rn}$ and radon progeny, which equals $0.4 ; D C F_{R n P}$ is the dose conversion factor for ${ }^{222} \mathrm{Rn}$, which equals $\left.1.7 \times 10^{-5} \mathrm{mSv}(\mathrm{Bq} \mathrm{h} \mathrm{m})^{-3}\right)^{-1}[3,20]$; and $\mathrm{T}$ is the time, which is $2000 \mathrm{~h}$ for the worker and $8 \mathrm{~h}$ a week, or $384 \mathrm{~h}$ annually, for the public. In Equation (4), $E_{\text {ext }}$ is the annual effective dose from external radiation; $H^{*}$ is the ambient dose equivalent rates $\left(\mathrm{nSv} \mathrm{h}^{-1}\right) ; \mathrm{CF}$ is the conversion factor from ambient dose equivalent rates to the absorbed dose in the air, which equals $0.652\left(\mathrm{~Gy} \mathrm{~Sv}^{-1}\right)$ [21]; and $D C F_{H-D}$ is the conversion factor from the absorbed dose in the air to the external effective dose, which equals 0.7 [1]. Finally, AED is the annual effective dose (mSv).

\section{Results and Discussion}

Natural hot springs are a popular tourist attraction in West Java. Since at least 1980, tourists have enjoyed the natural atmosphere of the area while participating in activities such as swimming, soaking, photographing the scenery, and walking in the park. Many even stay overnight [9-11]. Despite its diverse other uses, natural hot spring water in West Java is not used for drinking. Therefore, we performed dose assessments through inhalation and external dose radiation only.

From a total of 17 natural hot spring water samples and one mineral bottled water sample, the value of electroconductivity ranged from 0.164 to $1.925 \mathrm{mS} \mathrm{cm}^{-1}$ with an average value of $1.541 \mathrm{mS} \mathrm{cm}^{-1}$. Meanwhile, the $\mathrm{pH}$ ranged from 5 to 7 with an average value of 6 . Finally, water temperature, as shown in Table 1 , ranged from 36 to $42{ }^{\circ} \mathrm{C}$ with an average of $39^{\circ} \mathrm{C}$. According to the regulations of the Indonesian Ministry of Health [22], and the World Health Organisation [23], the E.C. and $\mathrm{pH}$ values in natural hot spring water samples in West Java fall above recommended values, which must be below $1.5 \mathrm{mS} \mathrm{cm}^{-1}$ and 6.5-8.5 for E.C. and pH, respectively. E.C. is closely related to the content of dissolved solids in the water. Thus, if water with a high E.C. value and $\mathrm{pH}$ level is used for drinking, gastrointestinal upset and kidney disease can result. Unlike the natural hot spring water samples, the mineral bottled water is suitable for drinking. 
Table 1. The location, physical and chemical properties of the water samples.

\begin{tabular}{|c|c|c|c|c|c|c|c|}
\hline \multirow{2}{*}{ Samples } & \multirow{2}{*}{ Area } & Longitude & Latitude & Elevation & Temperature & Electroconductivity at $25^{\circ} \mathrm{C}$ & \multirow{2}{*}{$\mathrm{pH}$} \\
\hline & & (E) & (S) & (m) & $\left({ }^{\circ} \mathrm{C}\right)$ & $(\mathrm{mS} \mathrm{cm}-1)$ & \\
\hline A1 & Cipanas & 107.8716 & -7.17643 & 1678 & 38 & 1.511 & 6 \\
\hline A2 & Cipanas & 107.8816 & -7.18884 & 1675 & 38 & 1.459 & 6 \\
\hline A3 & Cipanas & 107.7016 & -7.19645 & 1668 & 39 & 1.485 & 6 \\
\hline A4 & Cipanas & 107.5016 & -7.19646 & 1671 & 39 & 1.458 & 6 \\
\hline A5 & Darajat & 107.7415 & -7.21833 & 1672 & 37 & 1.442 & 6 \\
\hline A6 & Darajat & 107.7414 & -7.21914 & 1670 & 38 & 1.538 & 6 \\
\hline A7 & Darajat & 107.7416 & -7.22191 & 1672 & 37 & 1.586 & 6 \\
\hline A8 & Darajat & 107.7287 & -7.22935 & 1973 & 42 & 1.682 & 5 \\
\hline A9 & Darajat & 107.7287 & -7.22906 & 1976 & 42 & 1.628 & 5 \\
\hline A10 & Darajat & 107.7287 & -7.22851 & 1985 & 42 & 1.677 & 5 \\
\hline B1 & Ciwidey & 107.3843 & -7.14416 & 1779 & 37 & 1.425 & 6 \\
\hline $\mathrm{B} 2$ & Ciwidey & 107.3901 & -7.14710 & 1781 & 39 & 1.590 & 6 \\
\hline B3 & Ciwidey & 107.3853 & -7.14429 & 1724 & 36 & 1.385 & 6 \\
\hline B4 & Pangalengan & 107.6148 & -7.23211 & 1450 & 39 & 1.925 & 5 \\
\hline $\mathrm{C} 1$ & Ciater & 107.6544 & -6.80861 & 873 & 36 & 1.401 & 6 \\
\hline $\mathrm{C} 2$ & Ciater & 107.6544 & -6.80861 & 885 & 38 & 1.415 & 6 \\
\hline $\mathrm{C} 3$ & Ciater & 107.6544 & -6.80862 & 897 & 39 & 1.598 & 5 \\
\hline \multirow[t]{4}{*}{ M } & Bottled water & - & - & - & 25 & 0.164 & 7 \\
\hline & & $\min$ & & & 36 & 0.164 & 5 \\
\hline & & $\max$ & & & 42 & 1.925 & 7 \\
\hline & & average & & & 39 & 1.541 & 6 \\
\hline
\end{tabular}

The dissolved ${ }^{222} \mathrm{Rn}$ in water samples in the natural hot spring area shown in Figure 3 have a range of 1 to $31 \mathrm{~Bq} \mathrm{~L}^{-1}$. With the exceptions of water samples $\mathrm{A} 1, \mathrm{~B} 4$, and $\mathrm{C} 3$, these values were all below the maximum concentration limit (MCL), $11 \mathrm{~Bq} \mathrm{~L}^{-1}$, suggested by the EPA. Water samples from this natural hot spring area contained dissolved ${ }^{222} \mathrm{Rn}$ activity concentrations higher than the MCL but within the limit of the alternative maximum concentration level (AMCL) of $148 \mathrm{~Bq} \mathrm{~L}^{-1}$, also suggested by the EPA [4]. Based on the UNSCEAR 2000 report, the AMCL of $148 \mathrm{~Bq} \mathrm{~L}^{-1}$ is the limit determining the concentration of ${ }^{222} \mathrm{Rn}$ in the water that will produce an indoor ${ }^{222} \mathrm{Rn}$ increment equal to an outdoor ${ }^{222} \mathrm{Rn}$ activity concentration of $15 \mathrm{~Bq} \mathrm{~m}^{-3}$ with the transfer coefficient from water to indoor air applied as $1 \times 10^{-4}$ [18]. The ${ }^{222} \mathrm{Rn}$ activity concentration in natural hot spring water in the West Java province will contribute to an ${ }^{222} \mathrm{Rn}$ activity concentration in the air equal to $0.1-3.1 \mathrm{~Bq} \mathrm{~m}^{-3}$ concurrent to the ${ }^{222} \mathrm{Rn}$ activity concentration in air measured in this study as shown in Table 2.

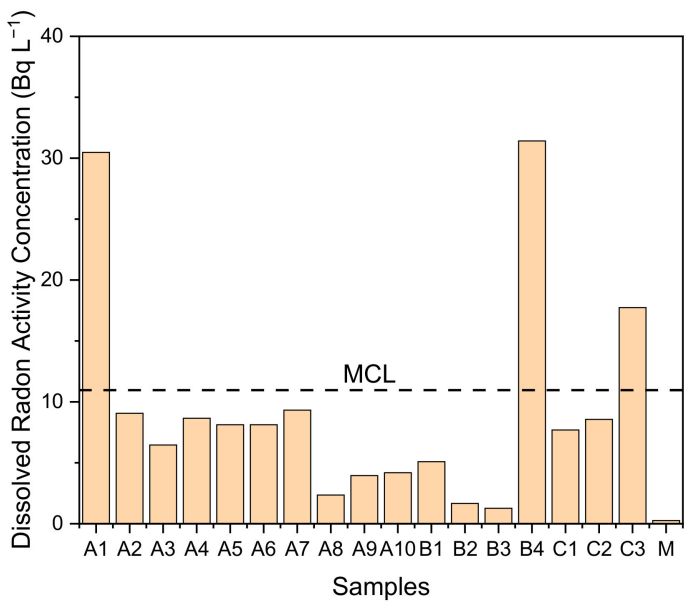

Figure 3. Radon activity concentration in water samples. MCL = maximum contaminant level. 
Table 2. Details of measuring result: Dissolved ${ }^{222} \mathrm{Rn}$ in water, ${ }^{222} \mathrm{Rn}$ in air, and calculation of annual effective dose.

\begin{tabular}{|c|c|c|c|c|c|c|c|c|c|c|c|}
\hline \multirow[t]{2}{*}{ Samples } & \multirow{2}{*}{$\begin{array}{c}\begin{array}{c}\text { Dissolved } \\
\text { Radon } \\
\text { in Water }\end{array} \\
\text { Bq L L }^{-1}\end{array}$} & \multirow{2}{*}{$\begin{array}{l}\begin{array}{c}\text { Radon } \\
\text { in Air }\end{array} \\
\text { Bq m }{ }^{-3} \\
\end{array}$} & \multirow{2}{*}{$\begin{array}{l}\text { Ambient } \\
\text { Dose } \\
\text { Equiva- } \\
\text { lent } \\
\text { Rate } \\
\text { nSv h}^{-1}\end{array}$} & \multirow[t]{2}{*}{$\begin{array}{l}\text { Radon } \\
\text { Transfer } \\
\text { Coeffi- } \\
\text { cient from } \\
\text { Water to } \\
\text { Air }\end{array}$} & \multirow{2}{*}{$\begin{array}{c}\text { Contributed } \\
\text { Dissolved } \\
\text { Radon in } \\
\text { Water to } \\
\text { Radon in Air } \\
\text { Bq m }{ }^{-3}\end{array}$} & \multicolumn{2}{|c|}{$\begin{array}{l}\text { Annual Effective } \\
\text { Dose due to } \\
\text { Ingestion (mSv) }\end{array}$} & \multicolumn{2}{|c|}{$\begin{array}{l}\text { Annual Effective } \\
\text { Dose due to } \\
\text { External Exposure } \\
(\mathrm{mSv})\end{array}$} & \multicolumn{2}{|c|}{$\begin{array}{l}\text { Total Annual } \\
\text { Effective Dose } \\
\text { (mSv) }\end{array}$} \\
\hline & & & & & & Worker & Public & Worker & Public & $\mathrm{Bq} \mathrm{L}^{-1}$ & $\mathrm{~Bq} \mathrm{~m}^{-3}$ \\
\hline A1 & $31 \pm 3.4$ & $48 \pm 7$ & $43 \pm 2$ & $5.9 \times 10^{-4}$ & 3.1 & 0.65 & 0.13 & 0.04 & 0.01 & 0.69 & 0.13 \\
\hline A2 & $9 \pm 1.0$ & $49 \pm 7$ & $41 \pm 2$ & $2.1 \times 10^{-3}$ & 0.9 & 0.67 & 0.13 & 0.04 & 0.01 & 0.70 & 0.14 \\
\hline A3 & $7 \pm 0.7$ & $42 \pm 6$ & $43 \pm 2$ & $1.8 \times 10^{-3}$ & 0.7 & 0.57 & 0.11 & 0.04 & 0.01 & 0.61 & 0.12 \\
\hline A4 & $9 \pm 1.0$ & $38 \pm 6$ & $41 \pm 2$ & $9.3 \times 10^{-4}$ & 0.9 & 0.52 & 0.10 & 0.04 & 0.01 & 0.55 & 0.11 \\
\hline A5 & $8 \pm 0.9$ & $39 \pm 6$ & $38 \pm 2$ & $1.1 \times 10^{-3}$ & 0.8 & 0.53 & 0.10 & 0.03 & 0.01 & 0.57 & 0.11 \\
\hline A6 & $8 \pm 0.9$ & $39 \pm 6$ & $37 \pm 2$ & $1.1 \times 10^{-3}$ & 0.8 & 0.53 & 0.10 & 0.03 & 0.01 & 0.56 & 0.11 \\
\hline A7 & $9 \pm 1.0$ & $40 \pm 6$ & $36 \pm 2$ & $1.1 \times 10^{-3}$ & 0.9 & 0.54 & 0.10 & 0.03 & 0.01 & 0.58 & 0.11 \\
\hline A8 & $2 \pm 0.3$ & $38 \pm 6$ & $40 \pm 2$ & $3.4 \times 10^{-3}$ & 0.3 & 0.52 & 0.10 & 0.04 & 0.01 & 0.55 & 0.11 \\
\hline A9 & $4 \pm 0.4$ & $38 \pm 6$ & $41 \pm 2$ & $2.0 \times 10^{-3}$ & 0.4 & 0.52 & 0.10 & 0.04 & 0.01 & 0.55 & 0.11 \\
\hline A10 & $4 \pm 0.5$ & $38 \pm 6$ & $40 \pm 2$ & $1.9 \times 10^{-3}$ & 0.4 & 0.52 & 0.10 & 0.04 & 0.01 & 0.55 & 0.11 \\
\hline B1 & $5 \pm 0.6$ & $38 \pm 6$ & $36 \pm 2$ & $2.0 \times 10^{-3}$ & 0.5 & 0.52 & 0.10 & 0.03 & 0.01 & 0.55 & 0.11 \\
\hline B2 & $2 \pm 0.2$ & $37 \pm 6$ & $38 \pm 2$ & $5.4 \times 10^{-3}$ & 0.2 & 0.50 & 0.10 & 0.03 & 0.01 & 0.54 & 0.10 \\
\hline B3 & $1 \pm 0.1$ & $35 \pm 6$ & $35 \pm 2$ & $5.5 \times 10^{-3}$ & 0.1 & 0.48 & 0.09 & 0.03 & 0.01 & 0.51 & 0.10 \\
\hline B4 & $31 \pm 3.5$ & $42 \pm 7$ & $44 \pm 2$ & $3.2 \times 10^{-4}$ & 3.1 & 0.57 & 0.11 & 0.04 & 0.01 & 0.61 & 0.12 \\
\hline $\mathrm{C} 1$ & $8 \pm 0.9$ & $48 \pm 7$ & $38 \pm 2$ & $1.7 \times 10^{-3}$ & 0.8 & 0.65 & 0.13 & 0.03 & 0.01 & 0.69 & 0.13 \\
\hline $\mathrm{C} 2$ & $8 \pm 0.9$ & $49 \pm 8$ & $37 \pm 2$ & $1.6 \times 10^{-3}$ & 0.9 & 0.67 & 0.13 & 0.03 & 0.01 & 0.70 & 0.13 \\
\hline $\mathrm{C} 3$ & $18 \pm 2.0$ & $50 \pm 8$ & $38 \pm 2$ & $2.0 \times 10^{-3}$ & 1.8 & 0.68 & 0.13 & 0.03 & 0.01 & 0.71 & 0.14 \\
\hline M & $0.3 \pm 0.1$ & - & - & - & 0.1 & - & & & & & \\
\hline Average & $9 \pm 1.0$ & $42 \pm 6$ & $39 \pm 2$ & $2.0 \times 10^{-3}$ & 0.9 & 0.53 & 0.11 & 0.04 & 0.01 & 0.60 & 0.12 \\
\hline $\min$ & $1 \pm 0.1$ & $35 \pm 5$ & $35 \pm 2$ & $3.2 \times 10^{-4}$ & 0.1 & 0.48 & 0.09 & 0.03 & 0.01 & 0.51 & 0.10 \\
\hline $\max$ & $31 \pm 3.5$ & $50 \pm 8$ & $44 \pm 2$ & $5.5 \times 10^{-3}$ & 3.1 & 0.68 & 0.13 & 0.04 & 0.01 & 0.71 & 0.14 \\
\hline
\end{tabular}

Comparing the values of ${ }^{222} \mathrm{Rn}$ levels in West Java to ${ }^{222} \mathrm{Rn}$ activity concentrations elsewhere reveal that Indonesian levels are rather low. Studies in Slovenia [24], the U.S. [25], Spain [26], Taiwan [27], Hungary [28], Poland [29], Venezuela [30], Germany [31], Croatia [32], Iran [33], and Thailand [6] report ${ }^{222} \mathrm{Rn}$ activity concentrations in hot spring water ranging from 0.2 to $600 \mathrm{~Bq} \mathrm{~L}^{-1}$. The radon concentration in an area is closely related to geological rock types, which in West Java have andesitic rock types that contain low uranium and radium content [34-36].

The radon activity concentration in the air in the hot spring area of the West Java province ranges from 35 to $50 \mathrm{~Bq} \mathrm{~m}^{-3}$ with an average of $42 \mathrm{~Bq} \mathrm{~m}^{-3}$. Equation (6) compares the activity value of the ${ }^{222} \mathrm{Rn}$ activity concentration dissolved in water and the ${ }^{222} \mathrm{Rn}$ in the air.

$$
\text { Transfer coefficient }=\frac{\overline{\Delta C_{a}}}{\overline{C_{w}}}
$$

here, $\Delta C_{a}$ is the average increment of ${ }^{222} \mathrm{Rn}$ activity concentration in the air $\left(\mathrm{Bq} \mathrm{m}{ }^{-3}\right)$. This result is a subtraction of the ${ }^{222} \mathrm{Rn}$ activity concentration in the air around the natural hot spring pool from the ${ }^{222} \mathrm{Rn}$ activity concentration outside of dwellings around the hot spring area. The ${ }^{222} \mathrm{Rn}$ activity concentration outside of dwellings around the hot spring area for Cipanas, Darajat, Ciwidey, Pangalengan and Ciater were 30, 30, 28, 32, and $35 \mathrm{~Bq}$ $\mathrm{m}^{-3}$, respectively. $C_{w}$ is the dissolved ${ }^{222} \mathrm{Rn}$ activity concentration in the water $\left(\mathrm{Bq} \mathrm{m}{ }^{-3}\right)$. The value of ${ }^{222} \mathrm{Rn}$ coefficient transfer from water to air in this study was an average of $2.0 \times 10^{-03}$. This value is higher than the value UNSCEAR [18] and Hopke et al. [19] found, possibly due to the effect of water mixing, since tourists were active in the pool while we conducted measurements. Others, including Radolic et al. [32] and Song et al. [37], have reported average transfer coefficients around $4.9 \times 10^{-3}$ and $1.5 \times 10^{-3}$, respectively.

The annual effective dose in the natural hot spring water area ranges from 0.51 to $0.71 \mathrm{mSv}$ with a mean of $0.60 \mathrm{mSv}$ for workers. Meanwhile, the public dose ranges from 0.10 to $0.14 \mathrm{mSv}$ with an average of $0.12 \mathrm{mSv}$. This value falls within the average committed 
effective dose from inhalation and terrestrial radiation for the general public, $1.7 \mathrm{mSv}$ annually, determined by UNSCEAR [1].

\section{Conclusions}

The concentration of ${ }^{222} \mathrm{Rn}$ in natural hot spring water samples in the West Java region of Indonesia has a range of 1 to $31 \mathrm{~Bq} \mathrm{~L}^{-1}$. An estimate of the annual effective dose in the natural hot spring water area ranges from 0.51 to $0.71 \mathrm{mSv}$ with a mean of $0.60 \mathrm{mSv}$ for workers. Meanwhile, the public is exposed to a range of 0.10 to $0.14 \mathrm{mSv}$ with an average of $0.12 \mathrm{mSv}$. This value falls within the range of the averaged committed effective dose from inhalation and terrestrial radiation for the general public, $1.7 \mathrm{mSv}$ annually.

Author Contributions: Conceptualisation, E.D.N., M.H. and S.T.; methodology, E.D.N., Y.T., K.K., M.H. and S.T.; validation, E.D.N., M.H, and U.U.; formal analysis, E.D.N., and M.H.; investigation, E.D.N., I.R.; resources, K.K., U.U., M.H. and S.T.; data curation, E.D.N.; writing-original draft preparation, E.D.N.; writing-review and editing, E.D.N., M.H., K.K., U.U., I.R., Y.T., O.B.M., C.K., J.M., and S.T.; visualisation, E.D.N.; supervision, M.H., J.M and S.T.; funding acquisition, M.H. and S.T. All authors have read and agreed to the published version of the manuscript.

Funding: This research was partially funded by the Indonesian Government, Japan Society for the Promotion of Science KAKENHI [20H00556, 18KK0261, 16K15368, 16H02667, JP18K10023], and Hirosaki University institutional research grant.

Institutional Review Board Statement: Not applicable.

Informed Consent Statement: Not applicable.

Conflicts of Interest: The authors declare no conflict of interest.

\section{References}

1. United Nations Scientific Committee on the Effects of Atomic Radiation. UNSCEAR 2008 Report, Sources and Effects of Ionising Radiation. Volume I: Annex B Exposures of the Public and Workers from Various Sources of Radiation; UNSCEAR: New York, NY, USA, 2010.

2. World Health Organization. WHO Handbook on Indoor Radon: A Public Health Perspective; WHO: Geneva, Switzerland, 2009.

3. International Commission on Radiological Protection. Annals of the ICRP: Occupational Intakes of Radionuclides: Part 3; ICRP: New York, NY, USA, 2017.

4. United State of America Environmental Protection Agency. USEPA (1991) National Primary Drinking Water Regulations: Radionuclides (Proposed Rule) Federal Register; U.S. E.P.A.: New York, NY, USA, 1991.

5. Gruber, V.; Maringer, F.J.; Landstetter, C. Radon and other natural radionuclides in drinking water in Austria: Measurement and assessment. Appl. Radiat. Isot. 2009, 67, 913-917. [CrossRef] [PubMed]

6. Sola, P.; Srisuksawad, K.; Loaharojanaphand, S. Radon activity concentration in air, hot spring water, and bottled mineral water in one hot spring area in Thailand. J. Radioanal. Nucl. Chem. 2013, 297, 183-187. [CrossRef]

7. Nugraha, E.D.; Hosoda, M.; Kusdiana, I.; Winarni, D.; Prihantoro, A.; Suzuki, T.; Tamakuma, Y.; Akata, N.; Tokonami, S. Dose assessment of radium-226 in drinking water from Mamuju, a high background radiation area of Indonesia. Radiat. Environ. Med. 2020, 9, 79-83.

8. Patricia, J.E. An assessment of Role of Natural Hot and Mineral Springs in Health, Wellness and Recreational Tourism. Ph.D. Thesis, James Cook University, Douglas, Australia, November 2011.

9. Fitriyani, P.; Waluya, B. The influence of competitive advantage in the tourist area of the hot spring water park, Sabda alam hotels and resorts Cipanas, Garut Regency in increasing visiting decisions (Pengaruh keunggulan bersaing di kawasan wisata air panas taman air sabda alam hotel dan resort cipanas kabupaten garut dalam meningkatkan keputusan berkunjung). Tour. Hosp. Essent. J. 2013, 1, 483.

10. Ananda, R.P.; Ahman, E.; Riwanudin, O. The effect of physical evidence of Ciwalini hot springs on the decision to visit tourists (Pengaruh physical evidence pemandian air panas ciwalini terhadap keputusan berkunjung wisatawan). Tour. Hosp. Essent. J. 2013, 1, 461.

11. Arif, M. Limit Proccess Application of Acceptable Change in Sari Ater Hot Spring Resort. Ph.D. Thesis, Tourism University, Hong Kong, January 2016.

12. Nugraha, W.; Kusdiana, E.D.; Iskandar, D. Radon activity concentrations in dwellings in East Kalimantan. In Proceedings of the National Seminar of Sains and Technology 2017, Bandung, Indonesia, 14 November 2017.

13. Nugraha, E.D.; Wahyudi, K.; Iskandar, D. Radon activity concentrations in dwelling of South Kalimantan, Indonesia. Radiat. Prot. Dosim. 2019, 184, 463-465. [CrossRef] 
14. Saputra, M.A.; Nugraha, E.D.; Purwanti, T.; Arifianto, R.; Laksmana, R.I.; Hutabarat, R.P.; Hosoda, M.; Tokonami, S. Exposures from radon, thoron, and thoron progeny in high background radiation area in Takandeang, Mamuju, Indonesia. Nukleonika 2020, 65, 89-94. [CrossRef]

15. Hosoda, M.; Nugraha, E.D.; Akata, N.; Yamada, R.; Tamakuma, Y.; Sasaki, M.; Kelleher, K.; Yoshinaga, S.; Suzuki, T.; Rattanapongs, C.P.; et al. A unique high natural background radiation area-Dose assessment and perspectives. Sci. Total Environ. 2021, 750, 142346. [CrossRef]

16. Iskandar, I.; Dermawan, F.A.; Sianipar, J.; Suryantini, Y.; Notosiswoyo, S. Characteristic and Mixing Mechanisms of Thermal Fluid at the Tampomas Volcano, West Java, Using Hydrogeochemistry, Stable Isotope and 222Rn Analyses. Geosciences 2018, 8, 103. [CrossRef]

17. Durridge. Manual Book of RAD7; Durridge Company Inc.: Billerica, MA, USA, 2018.

18. United Nations Scientific Committee on the Effects of Atomic Radiation. UNSCEAR 2000 Report, Sources and Effects of Ionising Radiation. Volume I: Annex B Exposures from Natural Radiation Sources; UNSCEAR: New York, NY, USA, 2000.

19. Hopke, P.K.; Borak, T.B.; Doull, J.; Cleaver, J.E.; Eckerman, K.F.; Gundersen, L.C.S.; Harley, N.H.; Hess, C.T.; Kinner, N.E.; Kopecky, K.J.; et al. Health risks due radon in drinking water. J. Environ Sci. Technol. 2000, 34, 921-926. [CrossRef]

20. Tokonami, S. Some thought on new dose conversion factors for radon progeny inhalation. Jpn J. Health Phys. 2018, 53, 282-293. [CrossRef]

21. Hosoda, M.; Fukui, Y.; Pornnumpa, C.; Sorimachi, S.; Ishikawa, T.; Yachi, M.; Nara, A.; Yokota, H.; Tokonami, S. Absorbed dose rate in air at the Bunkyo-cho Campus of Hirosaki University. Radiat. Environ. Med. 2014, 3, 59-62.

22. Ministry of Health of Indonesia. Drinking Water Quality Reference Level; Ministry of Health of Indonesia: Jakarta, Indonesia, 2002.

23. World Health Organization. WHO Guidelines for Drinking Water Quality, Vol. 1. Recommendations; WHO: Geneva, Switzerland, 2017.

24. Kobal, I.; Krista, J.; Ancik, M.; Jerencic, S.; Skofljanec, M. Radioactivity of thermal and mineral springs in Slovenia. Health Phys. 1979, 37, 239-242. [PubMed]

25. Nazaroff, W.; Nero, A. Radon and Its Decay Products in Air; John Wiley \& Sons: New York, NY, USA, 1988.

26. Soto, J.; Fernández, P.; Quindos, L.; Gomezarozamena, J. Radioactivity in Spanish spas. Sci. Total Environ. 1995, 162, 187-192. [CrossRef]

27. Sabol, J.; Weng, P.-S.; Mao, C.-H. Monitoring of ${ }^{222}$ Rn in Taiwanese Hot Spring SPA Waters Using a Modified Electret Ion Chamber Method. Health Phys. 1995, 68, 100-104. [CrossRef]

28. Szerbin, P. Natural radioactivity of certain spas and caves in Hungary. Environ. Int. 1996, 22, 389-398. [CrossRef]

29. Przylibski, T. ${ }^{222} \mathrm{Rn}$ concentration changes in medicinal groundwaters of Ladek Zdrój (Sudety Mountains, SW Poland). J. Environ. Radioact. 2000, 48, 327-347. [CrossRef]

30. Horvath, A.; Bohus, L.O.; Urbani, F.; Marx, G.; Piroth, A.; Greaves, E.D. Radon activity concentration in hot spring waters in northern Venezuela. J. Environ. Radioact. 2000, 47, 127-133. [CrossRef]

31. Trautmannsheimer, M.; Schindlmeier, W.; Boerner, K. Radon activity concentration measurements and personnel exposure levels in Bavarian water supply facilities. Health Phys. 2003, 84, 100-110. [CrossRef]

32. Radolić, V.; Vuković, B.; Smit, G.; Stanic, D.; Planinić, J. Radon in the spas of Croatia. J. Environ. Radioact. 2005, 83, 191-198. [CrossRef]

33. Jalili-Majareshin, A.; Behtash, A.; Rezaei-Ochbelagh, D. Radon activity concentration in hot springs of the touristic city of Sarein and methods to reduce radon in water. Radiat. Phys. Chem. 2012, 81, 749-757. [CrossRef]

34. Utami, P. Characteristics of the Kamojang geothermal reservoir (West Java) as revealed by its hydrothermal alteration mineralogy. In Proceedings of the World Geothermal Congress 2000, Sendai, Japan, 28 May-10 June 2000.

35. Sunarwan, B. Physical characterization of groundwater and identification of springs in the volcanic sediment aquifer (case study: Tangkuban perahu volcanic sediment in the Bandung basin) (karakterisasi phisik air tanah dan identifikasi pemunculan mata air pada akuifer endapan gunung api (studi kasus: Endapan gunungapi Tangkuban perahu di cekungan Bandung). Technol. J. Sci. Mag. Unpak. 2014, 15, 16-26.

36. Hidayat, M.R.; Mardiana, U.; Suganda, B.R.; Hadian, M.S.D. Geometry activities of Bandung area and surroundings, West Java Province (geometri akifer daerah Bandung dan sekitarnya, Provinsi Jawa Barat). Padjajaran Univ. Geom. Sci. J. $2017,1,86-97$.

37. Song, G.; Zhang, B.; Wang, X.; Gong, J.; Chan, D.; Bernett, J.; Lee, S.C. Indoor radon levels in selected hot spring hotels in Guangdong, China. Sci. Total Environ. 2005, 339, 63-70. [CrossRef] 